\title{
Strategi Pelestarian Keanekaragaman Ikan Endemik dan Lokal di Perairan Umum Kalimantan Selatan
}

\author{
[Diversity Preservation Strategy of Endemic and Local Fish \\ in South Kalimantan Public Waters]
}

Fahrur Razi ${ }^{1}$, Muh. Patekkai ${ }^{2}$

${ }^{1}$ Dinas Ketahanan Pangan, Pertanian dan Perikanan Kota Banjarbaru, Satminkal BPPP Banyuwangi ${ }^{2}$ Dinas Ketahanan Pangan dan Pertanian Kota Bogor, Satminkal BRPBATPP Bogor

\begin{abstract}
Abstrak
Salah satu alternatif untuk mempertahankan keanekaragaman ikan endemik dan lokal asli Kalimantan Selatan adalah melalui konservasi jenis pada tingkat pembudidaya ikan, dengan cara domestikasi dan budidaya. Tujuan dari studi ini adalah untuk menjelaskan karakteristik, spesies ikan endemik dan lokal asli, dan usaha konservasi. Metode yang digunakan dalam penelitian ini adalah penelitian kualitatif deskriptif. Hasil dari studi ini menunjukkan bahwa karakteristik habitat ikan endemik dan lokal Kalimantan di perairan darat secara umum dibagi menjadi dua yaitu kolam air tenang dan air deras. Perairan umum di Kalimantan Selatan kaya akan jenis ikan, lebih dari 394 jenis ikan, kebanyakan dari ikan-ikan tersebut termasuk dalam Ostariophysi dan Labyrinthici Perairan Sungai Barito, Kalimantan Selatan ditemukan 101 jenis ikan, terdiri dari 23 famili. Upayaupaya untuk melestarikan ikan endemik dan lokal dapat tercapai melalui pemacuan stok, distribusi ikan di perairan umum, peningkatan stok perikanan, dan pengembangan budidaya perikanan.
\end{abstract}

Kata kunci: konservasi; spesies ikan; stok; sungai

\section{Abstract}

One alternative is to maintain the biodiversity of endemic fish and local fish native to South Kalimantan through species conservation at the level of fish farmers, by means of domestication and cultivation. This study aims to explain the characteristics, species of endemic and local fish, and conservation efforts. The method used in research / assessment is descriptive qualitative research. The results of the study showed that the characteristics of endemic fish habitat and local Kalimantan Kalimantan fish in mainland waters are generally divided into two namely lotic water and lentic water. This habitat is generally in the form of public waters consisting of lakes, reservoirs, swamps, and rivers. Public waters in South Kalimantan have a richness of fish species of more than 394 species of fish, most of which belong to the order Ostariophysi and Labyrinthici, in the waters of the Barito River, South Kalimantan found 101 species of fish, consisting of 23 families. Efforts to preserve endemic fish and local fish that can be done through stock triggering through the distribution of fish in public waters, the development of fishery reserves, and the development of aquaculture.

Keywords: conservation; fish; river; species; stock

Penulis Korespondensi

Muh.Patekkai | patekkai.muhammad@gmail.com 


\section{PENDAHULUAN}

Produksi ikan dari hasil budidaya ikan air tawar sebagian besar (75,71\%) disumbangkan oleh komoditaskomoditas ikan introduksi yang sudah lama didomestikasi di Indonesia yaitu ikan mas, nila, lele dumbo, dan patin (KKP 2017). Produksi ikan-ikan lokal asli Indonesia tidak terinci tercatat, namun dikelompokkan ke dalam ikan lainnya yang tercatat sekitar $20 \%$ dari total produksi ikan air tawar.

Menurut Nugroho et al. (2012) perkembangan yang luas budidaya ikan non asli Indonesia (introduksi) yang sudah terdomestikasi baik ini di beberapa daerah menjadi salah satu penyebab mulai jarang bahkan sulitnya beberapa jenis ikan lokal asli Indonesia yang dapat ditemui di perairan umum, seperti ikan tambra di Hulu DAS Barito (Haryono dan Subagja 2008); ikan belida (Notopterus sp) dan patin sungai (Pangasius nasutus) serta ikan jelawat (Leptobarbus hoeveni) dianggap sudah jarang ditemukan (Petrus et al. 2008); ikan betutu (Oxyeleotris marmorata), dan tebirin (Belodontichthys dinema) (Utomo dan Asyari 1999).

Salah satu alternatif untuk menjaga biodiversitas ikan endemik Kalimantan Selatan melalui konservasi jenis di tingkat pembudidaya adalah dengan cara mendomestikasi dan membudidayakannya. Pengembangan budidaya berbasis ikan lokal ini dapat dijadikan pula sebagai upaya dalam mengembangkan budidaya ramah lingkungan, menanggulangi kemiskinan, dan menyediakan pangan bagi masyarakat lokal. Dengan latar belakang tersebut sangat perlu dilakukan penelitian/pengkajian tentang "Strategi Pelestarian Keanekaragaman Ikan Endemik di Perairan Umum Tawar Kalimantan Selatan".

Tujuan penelitian ini adalah: (a) Mengidentifikasi karakteristik habitat ikan endemik di perairan tawar Kalimantan Selatan; (b) Mengidentifikasi jenis ikan endemik potensial di Kalimantan Selatan; (c) Mengkaji tentang upaya pelestarian ikan endemik yang dapat dilakukan melalui pengaturan penangkapan; (d) Mengkaji tentang upaya pelestarian ikan endemik yang dapat dilakukan melalui suaka perikanan; (e) Mengkaji tentang upaya pelestarian ikan endemik yang dapat dilakukan melalui pemacuan stok; dan (f) Mengkaji tentang upaya pelestarian ikan endemik yang dapat dilakukan melalui budidaya perikanan.

\section{BAHAN DAN METODE}

Penelitian ini dilaksanakan di beberapa wilayah (Kota Banjarbaru, Kota Banjarmasin, Kabupaten Barito Kuala dan Kabupaten Banjar) Propinsi Kalimantan Selatan, yang berlangsung 
pada bulan Februari sampai dengan bulan April 2019.

Data-data yang disajikan terdiri dari data primer yang diperoleh dari wawancara dan observasi lapang, dan data sekunder diperoleh dari pustaka berupa buku-buku dan laman internet yang berhubungan dengan topik yang diangkat.

Metode yang digunakan dalam penelitian adalah metode survei. Data dianalisis secara deskriptif kualitatif. Data yang dikumpulkan meliputi data primer dan data sekunder. Pengumpulan dan pengolahan data sebagai berikut:

1. Pengumpulan data :(a) data primer diperoleh dari wawancara dan observasi lapang pada ekosistem perairan dan beberapa pasar ikan tradisional; dan (b) data sekunder diperoleh dari buku-buku, peraturan dan kajian-kajian ilmiah, serta laman internet.

2. Pengolahan data dan penyusunan kajian: Perumusan masalah yang diajukan dalam kajian, dengan penjabaran dan penggalian ide/gagasan utama dan ide pendukung dengan menggunakan 5 W (What, Who, When, Where, Why), dan $1 \mathrm{H}$ (How). Dalam rangka menjawab pertanyaan di atas, Penulis melakukan pengolahan data dan penelusuran pustaka yang dituangkan dalam beberapa sub bahasan.

\section{HASIL DAN PEMBAHASAN Karakteristik Habitat Ikan}

Perairan umum merupakan suatu area genangan air yang relatif luas yang dimiliki dan dikuasai oleh negara serta dimanfaatkan untuk kepentingan dan kesejahteraan masyarakat. Perairan umum meliputi danau, waduk, rawa, dan sungai.

Sungai merupakan badan air mengalir yang membentuk aliran di daerah daratan dari hulu menuju ke arah hilir dan akhirnya bermuara ke laut. Air sungai sangat berfungsi untuk memenuhi kebutuhan kehidupan organisme daratan seperti; tumbuhan, hewan, dan manusia di sekitarnya serta seluruh biota air di dalamnya (Downes et al. 2002). Sungai mempunyai fungsi utama menampung curah hujan dan mengalirkannya sampai ke laut. Ekosistem sungai merupakan habitat bagi organisme akuatik yang keberadaannya sangat dipengaruhi oleh lingkungan sekitarnya. Organisme akuatik tersebut diantaranya tumbuhan air, plankton, perifiton, bentos, ikan, serangga air, dan lain-lain. Sungai juga merupakan sumber air bagi masyarakat yang dimanfaatkan untuk berbagai keperluan dan kegiatan, seperti kebutuhan rumah tangga, pertanian, 
industri, sumber mineral, dan pemanfaatan lainnya (Soewarno 1991).

Menurut Akbar (2017) Kalimantan Selatan memiliki luas $37.530,52 \mathrm{~km}^{2}$ dan mempunyai potensi sumber daya perikanan yang cukup besar. Potensi tersebut meliputi perairan umum sekitar 1.000.000 ha berupa sungai dan anak sungai seluas 698.220 ha, danau alami, danau buatan/waduk seluas 9.200 ha, dan rawa banjiran seluas 292.580 ha.

Jika dilihat dari morfologinya, Kalimantan Selatan dibelah dua oleh pegunungan Meratus yang membentang dari selatan ke utara. Wilayah bagian timur Kalimantan Selatan merupakan daerah berbukit dan bergunung, sedangkan bagian Barat merupakan wilayah datar berupa daerah rawa, baik yang tergenang secara periodik maupun yang tergenang sepanjang tahun. Pada bagian Barat ini juga dilalui oleh sungai besar, yaitu Sungai Barito dan Sungai Kapuas beserta anak cabangnya, di mana sumber airnya berasal dari pegunungan Meratus. Sungai Barito terkenal sebagai sungai terlebar di Indonesia (Akbar 2014).

Kalimantan Selatan diantaranya memiliki perairan waduk (Riam Kanan) di Kabupaten Banjar, Danau Panggang di Kabupaten Hulu Sungai Utara, dan Danau Bangkau di Kabupaten Hulu Sungai Selatan tergolong tipe perairan rawa banjiran. Kondisi ini menunjukkan bahwa Kalimantan Selatan mempunyai potensi untuk membangun wilayah tersebut dari sektor perikanan (Dinas Perikanan dan Kelautan Kalimantan Selatan 2012).

Indonesia memiliki potensi rawa sekitar 33.393.570 ha terdiri atas lahan rawa pasang surut seluas 20.096 .800 ha, dan rawa lebak seluas 13.296.770 ha, yang tersebar di pulau Sumatera seluas 2.766.000 ha, Kalimantan seluas 3.580.500 ha, Sulawesi 644.500 ha, dan Papua seluas 6.305.770 ha (Subagyo 2006). Dari luasan rawa tersebut, total lahan rawa yang dikembangkan pemerintah 1.314.870 ha terdiri dari 835.200 ha rawa pasang surut, dan 479.670 ha rawa lebak.

\section{Jenis Ikan Endemik dan Ikan Lokal Air Tawar}

Indonesia dengan keanekaragaman hayati yang luar biasa besarnya, memiliki sekitar $16 \%$ dari spesies ikan dunia hidup di Indonesia. Di perairan Indonesia sendiri terdapat lebih dari 7.000 spesies ikan, di mana 2.000 spesies diantaranya adalah ikan air tawar.

Menurut Kottelat et al. (1993) secara zoo-geografis, penyebaran ikan di Indonesia dapat dikelompokkan menjadi 3 bagian, yaitu: 1) kelompok ikan di Paparan Sunda (Jawa, Bali, Kalimantan, dan Sumatera), 2) kelompok ikan di Paparan Sahul (Papua Barat dan 
Kepulauan Maluku), dan 3) kelompok ikan di Paparan Wallace (Sulawesi dan Nusa Tenggara). Jenis ikan terbanyak terdapat di Paparan Sunda (798 jenis), kemudian diikuti oleh Paparan Sahul (106 jenis), dan Paparan Wallace (68 jenis).

Perairan umum di Kalimantan mempunyai kekayaan jenis ikan lebih dari 394 jenis ikan yang sebagian besar termasuk ke dalam ordo Ostariophysi dan Labyrinthici (Kottelat et al. 1993). Sedangkan jenis ikan di perairan umum Kalimantan Selatan ditaksir sekitar 200300 jenis ikan (Chairuddin 1989). Jenis ikan tersebut tersebar di perairan sungai, rawa banjiran, dan perairan lainnya antara lain bekas galian pasir, batu bara di semua wilayah Kabupaten/Kota, dan waduk di Kabupaten Banjar (Waduk Riam Kanan). Jenis ikan yang terdapat di sungai Barito Kalimantan Selatan, kelimpahan ikan tertinggi di anak sungai $(45,39 \%)$, diikuti oleh sungai $(28,96 \%)$, dan rawa (25,65\%) (Sunarno et al. 2008).

Dari hasil penelitian Prasetyo dan Asyari (2003) di perairan Sungai Barito, Kalimantan Selatan ditemukan 101 jenis ikan, yang terdiri atas 23 famili dan 1 jenis udang. Jenis ikan yang terbanyak di sepanjang perairan Sungai Barito terdiri dari famili Cyprinidae (39 jenis), Siluridae (11 jenis), dan Bagridae (11 jenis).

Besarnya jumlah anggota famili Cyprinidae yang ditemukan, disebabkan famili ini merupakan famili ikan air tawar yang terbesar di setiap tempat di dunia, kecuali Australia, Madagaskar, Selandia Baru, dan Amerika Selatan.

\section{Upaya Pelestarian Ikan Endemik/Lokal Melalui Pengaturan Penangkapan}

Dalam rangka mendukung pembangunan perikanan berkelanjutan perlu disosialisasikan tentang pengaturan penggunaan alat penangkapan ikan sebagai strategi pengembangan usaha perikanan yang dilaksanakan dengan cara-cara yang bijak dan bertanggung jawab, dengan memperhatikan keberlanjutan ekologi, sosial, ekonomi dan kelestarian sumber daya perikanan. Menurut (Akbar 2017) Pengaturan penangkapan ikan di perairan umum (rawa) Kalimantan Selatan merupakan salah satu aspek pelestarian sumber daya plasma nutfah perikanan. Dalam upaya ini ada beberapa aspek penangkapan yang sangat penting untuk diperhatikan, yaitu: (1) pengaturan penangkapan yang berhubungan dengan ukuran alat tangkap, (2) operasional alat tangkap, (3) daerah penangkapan, (4) penangkapan dengan alat atau bahan terlarang, dan (5) pengaturan terhadap jumlah upaya penangkapan (fishing effort). 
Tabel 1. Alat tangkap di perairan umum daratan di Kalimantan Selatan

\begin{tabular}{|c|c|c|c|c|c|}
\hline No & Jenis Alat Tangkap & Sungai & Rawa & Waduk & Lain \\
\hline 1 & Jaring insang hanyut & $\sqrt{ }$ & & & \\
\hline 2 & Jaring insang tetap & $\sqrt{ }$ & $\sqrt{ }$ & $\sqrt{ }$ & $\sqrt{ }$ \\
\hline 3 & Anco & $\sqrt{ }$ & $\sqrt{ }$ & & $\sqrt{ }$ \\
\hline 4 & Serok & $\sqrt{ }$ & & & \\
\hline 5 & Rawai & $\sqrt{ }$ & $\sqrt{ }$ & $\sqrt{ }$ & \\
\hline 6 & Pancing & $\sqrt{ }$ & $\sqrt{ }$ & $\sqrt{ }$ & $\sqrt{ }$ \\
\hline 7 & Serok & $\sqrt{ }$ & $\sqrt{ }$ & $\sqrt{ }$ & $\sqrt{ }$ \\
\hline 8 & Jermal & $\sqrt{ }$ & & & \\
\hline 9 & Bubu & $\sqrt{ }$ & $\sqrt{ }$ & $\sqrt{ }$ & $\sqrt{ }$ \\
\hline 10 & Jala tebar & $\sqrt{ }$ & $\sqrt{ }$ & $\sqrt{ }$ & \\
\hline 11 & Lain-lainnya & $\sqrt{ }$ & $\sqrt{ }$ & & $\sqrt{ }$ \\
\hline
\end{tabular}

Sumber:.Sunarno et al. (2008)

Saat musim kemarau sampai menjelang air musim penghujan (Agustus-November) biasanya ikan-ikan perairan umum gonadnya sudah berkembang bahkan kadang-kadang ditemukan sudah memijah. Oleh karena itu, pada saat-saat tersebut di atas operasional alat harus diperhatikan betul karena pada saat itu ikan-ikan yang sedang memijah (berisi telur), perlu adanya pelarangan penangkapan yang dituangkan dalam Peraturan Daerah. Hal ini senada dengan pendapat (Direktorat Kawasan Jenis Ikan 2015) bahwa untuk mengatasi lebih tangkap dapat dilakukan dengan pengaturan waktu tangkap untuk menghindari tertangkapnya jenis ikan yang sedang dalam musim pemijahan.

Upaya pelestarian sumber daya plasma nutfah dengan mengatur musim, waktu, dan daerah-daerah penangkapan ini akan berhasil bila diimbangi dengan usaha pengawasan di lapangan, karena selama ini banyak daerah-daerah larangan penangkapan akan tetapi tidak diindahkan oleh pencari ikan. Upaya perlindungan seperti di atas biasanya diterapkan pada perairan lebak lebung, danau, waduk, dan genangan air lainnya.

Alat tangkap yang umum digunakan nelayan sekitar rawa di Kalimantan Selatan merupakan alat tangkap tradisional dengan prinsip sebagai perangkap (traps). Jenis alat tangkap di perairan umum Kalimantan Selatan terlihat pada Tabel 1.

Dalam pelestarian plasma nutfah perikanan, pengawasan terhadap penangkapan ikan sangat penting artinya, pengawasan dapat dilakukan oleh pemerintah, masyarakat nelayan, 
kelompok tani atau lembaga sosial masyarakat (LSM). Selain itu, penyuluhan yang intensif tentang pentingnya pelestarian plasma nutfah perikanan di perairan umum juga perlu dilakukan. Untuk lebih menjamin berjalannya pengaturan atau cara-cara penangkapan ikan ini, sangat diperlukan penegakan hukum yang tegas bagi yang terbukti melakukan pelanggaran penangkapan ikan dengan alat-alat yang dilarang tersebut.

\section{Upaya Pelestarian Ikan Endemik/Lokal Melalui Suaka Perikanan}

Suaka perikanan (reservat) adalah suatu ekosistem perairan yang memiliki daerah yang terbatas, di mana semua kegiatan penangkapan biota perairan dengan cara apapun, kapanpun dan oleh siapapun, dilarang, karena memiliki fungsi sebagai tempat pelestarian ikanikan endemik yang langka (atau hampir punah) dan beberapa spesies yang dilindungi keberadaannya. Pembentukan suaka perikanan ditujukan untuk melindungi habitat ikan endemik, agar terhindar dari upaya penangkapan tehadap jenis tersebut. Suaka perikanan bisa ditetapkan di kawasan yang berfungsi sebagai tempat berlindung/berkembangbiak.

Pembentukan suaka perikanan ditujukan agar ikan ikan tersebut mampu berkembangbiak secara alami.
Pembentukan suaka perikanan biasanya ditujukan untuk jenis ikan yang mengalami eksploitasi berlebihan (Prianto et al. 2017).

Suaka perikanan secara khusus merupakan tempat penelitian biota endemik yang langka, dan beberapa spesies yang hampir punah untuk dikembangbiakan dengan meneliti cara makan, beradaptasi, pemijahan, dan pakan alami dari larva sampai menjadi dewasa, agar bisa dikembalikan kembali ke habitat semula untuk menjaga keseimbangan ekosistem. Penetapan suaka perikanan harus mengacu kepada kondisi ekologi perairan dan melibatkan masyarakat nelayan setempat. Lokasi yang akan dijadikan suaka perikanan harus memenuhi persyaratan ekologi, ekonomi dan sosial budaya sehingga keberadaannya dapat berfungsi dengan baik (Prianto et al. 2016).

Di perairan umum Kalimantan Selatan ditaksir ada sekurang-kurangnya 200-300 jenis ikan (Chairuddin 1989). Sedangkan hasil penelitian Prasetyo dan Asyari (2003), Keanekaragaman jenis ikan di Sungai Barito Kalimantan Selatan telah diidentifikasi berjumlah 101 jenis dari 23 famili dan 1 jenis udang. Jumlah ikan air tawar yang tercatat saat ini di Kalimantan Selatan diduga masih di bawah angka perkiraan karena masih banyaknya jenis yang belum diteliti dan dideskripsikan. 
Untuk

melestarikan, mempertahankan plasma nutfah, dan produksi ikan yang berkelanjutan dapat dilakukan dengan cara memberi perlindungan terhadap ikan dan ekosistemnya agar dapat berkembang biak dan lestari. Upaya pengelolaan perikanan perairan umum untuk pelestarian plasma nutfah perikanan tersebut dapat dilakukan dengan pembentukan suaka perikanan (reservat), pengaturan penangkapan, pemacuan stok (stock enhancement) dengan cara penebaran (stoking, restocking, dan introduksi), dan budidaya perikanan.

Pemanfaatan plasma nutfah perikanan sebagai ikan konsumsi maupun sebagai ikan hias telah lama dilakukan masyarakat Indonesia, yang harus diperhatikan dalam pemanfaatan sumber daya plasma nutfah adalah aspek pelestariannya agar pemanfaatannya dapat berkelanjutan. Manajemen dan kebijakan yang mengatur pemanfaatan plasma nutfah secara berkelanjutan tersebut perlu dilakukan pemerintah dengan peran serta dukungan masyarakat.

Kegiatan yang memanfaatkan plasma nutfah perikanan di perairan umum dapat digolongkan atas 2 macam, yaitu: 1) kegiatan penangkapan, baik ikan konsumsi, ikan hias, dan benih ikan, serta 2) kegiatan pemeliharaan atau budi daya. Apapun bentuk kegiatan yang memanfaatkan plasma nutfah perikanan, haruslah dilakukan secara bijaksana agar dapat memelihara daya dukung serta kelestarian sumber daya perikanan tersebut.

Menurut (Asyari 2009) Sungai Barito yang panjangnya sekitar 900 km merupakan sungai besar yang penting di Kalimantan. Menurut Prasetyo dan Utomo (1994) bagian hulu sungai Barito terletak di Serawak Malaysia dan Kalimantan Tengah, sedangkan bagian hilir atau muaranya terletak di Provinsi Kalimantan Selatan (laut Jawa). Sungai Barito merupakan sungai yang sangat kompleks ditinjau dari zona perairannya, mulai dari zona berarus deras, berarus sedang sampai berarus tenang. Daerah aliran sugai (DAS )Barito mempunyai banyak anak sungai, danau, sungai mati maupun hutan rawa yang digenangi air.

Perairan Sungai Barito di Kalimantan Selatan mempunyai peranan penting bagi kehidupan masyarakat nelayan di sekitar perairan sebagai sumber lapangan kerja, mata pencaharian, transportasi, pangan, dan ikan. Menurut Prasetyo dan Utomo (1994), di Sungai Barito ditemukan 101 jenis ikan, tersebar $80 \%$ bagian tengah, $10 \%$ bagian hulu, dan $10 \%$ bagian hilir.

Pada DAS Barito Kalimantan Selatan terdapat 9 suaka perikanan yang tersebar di beberapa wilayah kabupaten, 
yaitu: Alalak Padang, Rawa Muning, Danau Bangkau, Awang Landas, Banyu Hirang, Danau Panggang, Danau Talan, Sungai Sambujur, dan Babirik (Asyari 2009). Secara umum, luas perairan rawa yang dijadikan sebagai suaka perikanan adalah sekitar 5 - 40\% dari luas total rawa.

Kebanyakan suaka perikanan yang ada di DAS Barito Kalimantan Selatan ini belum berfungsi dengan baik, ini disebabkan antara lain: tidak adanya batas yang jelas dari suaka tersebut, adanya pendangkalan dan banyaknya gulma air serta larangan penangkapan yang kurang dipatuhi masyarakat (Sarnita 1993). Upaya untuk memfungsikan suaka perikanan secara maksimal, maka yang harus dilindungi tidak hanya ikannya saja, tetapi juga habitatnya yang sesuai bagi tempat pemijahan, tempat mencari makan dan tempat naungan (berupa tumbuhan air) bagi telur dan larva ikan. Selain itu harus ada jalur migrasi berupa anak sungai atau kanal, sehingga ikan dapat keluar dan menyebar ke daerah sekitarnya, mempunyai kedalaman yang cukup dan juga kualitas perairan yang baik serta cukup tersedianya pakan alami.

\section{Upaya Pelestarian Ikan Endemik/Lokal Melalui Pemacuan Stok}

Pemacuan stok ikan merupakan sebagai aktivitas yang ditujukan untuk menambah atau melestarikan rekruitmen satu atau lebih organisme perairan dan meningkatkan total produksi atau unsur produksi yang dipilih dari suatu perikanan yang berada di bawah tingkat lestari dari proses alami. Pemacuan stok ikan merupakan alat pengelolaan sumberdaya ikan atau proses pengelolaan sumberdaya. Pemacuan stok merupakan suatu teknik manipulasi stok untuk meningkatkan populasi ikan sehingga total hasil tangkapan atau hasil tangkapan jenis ikan tertentu meningkat. Upaya pemacuan stok ikan dilakukan di perairan yang produktivitas alaminya tinggi, tetapi rekruitmen alaminya terbatas.

Pemacuan sumberdaya ikan pada umumnya ditujukan untuk meningkatkan hasil tangkapan ikan atau memperbaiki populasi ikan karena populasi ikan di perairan tersebut menurun. Penurunan populasi ikan dapat diakibatkan oleh berbagai faktor, antara lain penangkapan yang intensif, perubahan habitat sehingga tidak sesuai dengan komunitas ikan asli, sumberdaya pakan, dan relung ekologis ( $n i c h e$ ) yang tidak dimanfaatkan secara optimal.

Pemacuan sumberdaya ikan juga dimaksudkan untuk memperbaiki kuantitas dan kualitas stok ikan yang memijah sehingga memperbaiki potensi reproduksi alaminya. Dengan demikian, jika potensi reproduksi alami tersebut 
berhasil diperbaiki, maka dampak penebaran ikan terhadap pemacuan sumberdaya ikan akan berlangsung lama sehingga tidak perlu dilakukan penebaran berulang-ulang.

Pada umumnya penebaran (stocking) bertujuan untuk menambah jenis ikan dan untuk meningkatkan produksi suatu perairan. Diharapkan ikan tersebut tumbuh cepat dan berkembang biak sehingga tidak memerlukan penebaran kembali secara teratur. Dengan adanya penebaran ulang (restocking) biasanya populasi ikan yang lama akan terdesak dengan populasi ikan yang baru, hal ini dikarenakan populasi ikan yang baru akan menang dalam bersaing, khususnya dalam mendapatkan makanan karena jumlahnya lebih banyak dan dominan.

Pada hakekatnya penebaran jenis ikan pada suatu perairan merupakan suatu pemasukan unsur baru pada suatu ekosistem tertentu, sehingga mengubah keseimbangan hayati ke arah yang dikehendaki, seperti lingkungan dan pakan alami yang sesuai. Beberapa ekosistem masih banyak terdapat relung ekologi yang kosong. Diharapkan dengan adanya penebaran maka dapat mengisi kekosongan relung ekologi tersebut.

Menurut Kartamihardja dan Umar (2017), kesuksesan strategi pemacuan stok ikan akan berhasil jika didasarkan pada protokol dan langkah-langkah yang jelas. Metodlogi antara lain sebagai berikut; 1) Penebaran untuk memacu atau mendukung kemampuan rekruitmen secara alami. 2) Rekayasa lingkungan atau modifikasi atau manipulasi habitat untuk memperbaiki laju rekruitmen dan atau pertumbuhan, jalur ruaya dan tempat perlindungan ikan, serta sumberdaya pakan alami. 3) Eliminasi jenis-jenis ikan yang tidak dikehendaki. 4) Penyuburan perairan untuk meningkatkan produktivitas. 5) Introduksi jenis ikan baru dalam rangka optimalisasi pemanfaatan relung (niche) ekologi. 6) Penebaran ikan dalam rangka pengembangan perikanan berbasis budidaya (culture based fisheries).

\section{Upaya Pelestarian Ikan Endemik/Lokal Melalui Budidaya Perikanan}

Budidaya perikanan merupakan usaha pemeliharaan dan pengembangbiakan ikan atau organisme air lainnya di lingkungan terkontrol dalam rangka mendapatkan keuntungan. Budidaya perikanan adalah usaha pemeliharaan dan pengembangbiakan ikan atau organisme air lainnya.

Peningkatan permintaan ikan akan mendorong upaya untuk meningkatkan kualitas mutu produk perikanan sehingga dapat bersaing, melalui: (a) efisiensi biaya produksi, (b) peningkatan mutu produk agar diterima pasar, (c) jaringan 
pemasaran yang lebih luas, dan (d) perencanaan produksi untuk menghasilkan output dan manfaat yang lebih besar (Bank Indonesia 2010). Dalam pengelolaan usaha perikanan budidaya, hal teknis yang perlu mendapat perhatian serius adalah: pengelolaan air, sarana produksi, cara budidaya, penggunaan pakan dan produksi yang belum efisien. Salah satu cara mengatasinya adalah melalui penerapan strategi pengembangan usaha budidaya ikan yang tepat (Rahmawati dan Dede 2012).

Menurut Koten et al. (2015), beberapa faktor yang perlu dikaji dan dievaluasi dalam pengelolaan usaha budidaya ikan, yaitu: ketersediaan air (jumlah dan mutu air), keadaan tanah dan topografi (keadaan muka tanah), status kepemilikan tanah, jenis ikan yang dibudidayakan, keadaan pasar, ketersediaan tenaga kerja, makanan ikan serta ketersediaan sarana dan prasarana.

Secara umum strategi pelestarian keanekaragaman ikan endemik dan lokal di perairan danau, sungai dan rawa Kalimantan Selatan melalui kegiatan budidaya ikan, dapat dilakukan pada semua jenis ikan endemik dan ikan lokal yang ada. Tetapi pada praktek penerapannya oleh masyarakat, hanya dibatasi pada jenis ikan potensial yang menguntungkan, baik sebagai ikan konsumsi maupun ikan hias.

Jenis ikan yang dipelihara harus memenuhi persyaratan sebagai berikut: tahan terhadap lingkungan hidup baru, laju pertumbuhannya cukup tinggi, mampu berkembang biak dalam keadaan tertangkap, mampu menyesuaikan diri terhadap pakan buatan yang diberikan, dapat dibudidayakan dengan kepadatan tinggi, tahan terhadap penyakit, mempunyai harga pasaran yang cukup tinggi, dan memenuhi selera konsumen. Menurut (Akbar 2017) sistem budidaya ikan yang dapat dikembangkan di lahan perairan tawar Kalimantan Selatan 4 jenis, yaitu: sistem kolam, sistem karamba, sistem jaring tancap, dan sistem fish pen/hampang.

Beberapa jenis ikan lokal potensial yang sudah tersedia benih unggul hasil budidaya, baik oleh Balai Benih Ikan Pemerintah (seperti BBAT Mandiangin, BBI Sentral, maupun BBI yang tersebar di 13 kabupaten/kota) di Kalimantan Selatan, maupun oleh Unit Pembenihan Rakyat (UPR), diantaranya adalah: ikan papuyu, gabus, kalui/gurame, patin, kelabau dan baung.

Tingkat penerapan teknologi budidaya dalam akuakultur berbedabeda, perbedaan tingkat teknologi ini akan berpengaruh terhadap produksi dan produktivitas yang dihasilkan. 
Berdasarkan tingkat teknologi dan produksi yang dihasilkan, kegiatan akuakultur dapat dibedakan menjadi akuakultur yang ekstensif atau tradisional, akuakultur yang semi intensif, akuakultur intensif, dan akuakultur hiper intensif.

\section{SIMPULAN}

Karakteristik habitat ikan endemik dan ikan lokal Kalimantan Selataan di perairan daratan secara umum dibagi menjadi 2 yaitu perairan mengalir (lotic water) dan perairan menggenang (lentic water). Habitat ini umumnya berupa perairan umum yang terdiri dari danau, waduk, rawa, dan sungai. Dimana, perairan umum merupakan suatu area genangan air yang relatif luas yang dimiliki dan dikuasai oleh negara serta dimanfaatkan untuk kepentingan dan kesejahteraan masyarakat.

Perairan umum di Kalimantan Selatan mempunyai kekayaan jenis ikan lebih dari 394 jenis ikan yang sebagian besar termasuk ke dalam ordo Ostariophysi dan Labyrinthici. Dari hasil penelitian Prasetyo dan Asyari (2003) di perairan Sungai Barito, Kalimantan Selatan ditemukan 101 jenis ikan, yang terdiri atas 23 famili dan 1 jenis udang. Jenis ikan yang terbanyak di sepanjang perairan Sungai Barito terdiri dari famili Cyprinidae (39 jenis), Siluridae (11 jenis), dan Bagridae (11 jenis).
Penurunan potensi plasma nutfah perikanan biasanya disebabkan antara lain oleh kegiatan penangkapan yang tidak ramah lingkungan, penangkapan yang berlebihan, dan adanya kerusakan lingkungan, oleh karenanya diperlukan pengaturan: penggunaan ukuran alat tangkap; operasional alat; musim, waktu, dan daerah penangkapan; jumlah dan jenis ikan hasil penangkapan; jenis-jenis alat tangkap yang diperbolehkan; dan penggunaan alat tangkap ikan yang ramah lingkungan

Pengembangan suaka perikanan, khususnya sebagai daerah pemijahan, menjadi penting dalam tindakan mencegah kepunahan ikan-ikan endemik dan ikan lokal, dengan memberikan peluang kepada ikan-ikan untuk melakukan proses reproduksinya secara normal. Pendirian suaka di beberapa tempat di perairan sangat dibutuhkan untuk mempertahankan kelestarian sumber daya perikanan.

Upaya pelestarian ikan endemik dan ikan lokal yang dapat dilakukan melalui pemacuan stok melalui penebaran ikan di perairan umum, yaitu: mengintroduksikan jenis dari luar kawasan, dan memindahkan jenis ikan di kawasan tersebut. Pada umumnya penebaran bertujuan untuk menambah jenis ikan dan untuk meningkatkan produksi suatu perairan. 
Ikan-ikan endemik dan lokal mempunyai nilai ekonomis penting di Kalimantan Selatan, walaupun demikian, ketersediaannya cenderung menurun sebagai akibat penangkapan yang semakin intensif guna memenuhi kebutuhan yang semakin besar seiring dengan pertambahan penduduk. Untuk mengatasi hal tersebut salah satu upaya adalah dengan pengembangan budidaya perikanan untuk di perairan tawar, yaitu: sistem kolam, sistem karamba, sistem jaring apung, dan sistem fish pen atau hampang.

\section{DAFTAR PUSTAKA}

Akbar, Junius. 2014. Potensi dan tantangan budi daya ikan rawa (ikan hitaman dan ikan putihan) di kalimantan selatan. Banjarmasin (ID): Lambung Mangkurat University Press.

Akbar, Junius. 2017. Potensi Peluang dan Tantangan Pengembangan Perikanan Rawa di Kalimantan Selatan. Banjarmasin (ID): Lambung Mangkurat University Press.

Asyari. 2009. “Upaya Pelestarian Plasma

Nutfah Perikanan di Perairan Umum." Hal. 1-12 in Seminar Nasional Tahunan VI. Hasil Penelitian Perikanan dan Kelautan. Yogyakarta (ID): Universitas Gadjah Mada.
Bank Indonesia. 2010. Pola Pembiayaan Usaha Kecil (PPUK) Pembenihan Ikan Lele. Jakarta (ID): Direktorat Kredit, BPR dan UKM. Biro Pengembangan BPR dan UKM.

Chairuddin, $\quad$ Gusti. 1989.

"Keanekaragaman jenis ikan konservasi di kawasan lahan basah Sungai Negara." Hal. 17890 in Prosiding Temu Karya IImiah.

Perikanan Rakyat. Jakarta (ID): Badan Penelitian dan Pengembangan Pertanian.

Dinas Perikanan dan Kelautan Kalimantan Selatan. 2012. Statistik Perikanan Provinsi Kalimantan Selatan. Banjarbaru (ID).

Direktorat Kawasan Jenis Ikan. 2015. Pedoman Umum Restoking Jenis Ikan Terancam Punah. Jakarta (ID).

Downes, Barbara J., Leon A. Barmuta, Peter G. Fairweather, Daniel P. Faith, Michel J. Keough, Phillip Sam Lake, Bruce D. Mapstone, dan Gerry P. Quinn. 2002. Monitoring ecological impacts: concepts and practice in flowing waters. Cambridge University Press. 
Haryono, dan Jojo Subagja. 2008. "Populasi dan Habitat Ikan Tambra, Tor tambroides (Bleeker, 1854) di Perairan Kawasan Pegunungan Muller Kalimantan Tengah.” Biodiversitas 9(4):306-9.

Kartamihardja, Endi Setiadi, dan Chairulwan Umar. 2017. "Kebijakan Pemacuan

Sumberdaya Ikan Di Perairan Umum Daratan Indonesia: Teknologi Alternatif Untuk Meningkatkan Produksi Ikan Dan Pendapatan Nelayan." Jurnal Kebijakan Perikanan Indonesia 1(2):99. doi:

10.15578/jkpi.1.2.2009.99-111.

KKP. 2017. Kelautan dan Perikanan Dalam Angka Tahun 2016. Jakarta (ID): Pusat Data Statistik dan Informasi, Kementerian Kelautan dan Perikanan.

Koten, Elias, Lukas L. J. J. Mondoringin, dan Indra R. N. Salindeho. 2015. "Evaluasi Usaha Pembudidayaan Ikan di Desa Matungkas Kabupaten Minahasa Utara." eJournal BUDIDAYA PERAIRAN $3(1)$.

doi:

10.35800/bdp.3.1.2015.6971.
Kottelat, Maurice, Anthony J. Whitten, Sri Nurani Kartikasari, dan Soetikno Wirjoatmodjo. 1993. Freshwater fishes of western Indonesia and Sulawesi. Jakarta (ID): Jakarta (Indonesia) Periplus Ed.

Nugroho, Ristiawan Agung, Lilik Teguh Pambudi, Diana Chilmawati, dan Alfabetian Herjuno Condro Haditomo. 2012. "Aplikasi Teknologi Aquaponic Pada Budidaya Ikan Air Tawar Untuk Optimalisasi Kapasitas Produksi." Jurnal Saintek Perikanan 8(1):4651. doi: 10.14710/ijfst.8.1.p.

Petrus, M., S. Erayani, S. Irmayuti, ATS Magat, Penni Mukhroni, E. Florensi, dan E. Jumat. 2008. Jenis Ikan Air Tawar dan Daerah Sebarannya di Kalimantan Tengah. Palangkaraya (ID): Dinas Kelautan dan Perikanan Provinsi Kalimantan Tengah.

Prasetyo, D., dan Asyari. 2003. "Inventarisasi jenis ikan dan karakteristik limnologist Sungai Barito." Hal. 23-31 in Prosiding Pusat Riset Perikanan Tangkap.

Prasetyo, D., dan A. D. Utomo. 1994. "Potensi sumber daya perikanan perairan umum Lebak Lebung." Jurnal Penelitian dan Pengembangan Pertanian 13(3):83-90. 
Prianto, Eko, Endi S. Kartamihardja, Chairulwan Umar, dan Kamaluddin Kasim. 2016. "Pengelolaan Sumberdaya Ikan Di Komplek Danau Malili Provinsi Sulawesi Selatan." Jurnal Kebijakan Perikanan Indonesia 8(1):41. doi: 10.15578/jkpi.8.1.2016.41-52.

Prianto, Eko, Reni Puspasari, Dian Oktaviani, dan Aisyah Aisyah. 2017. "Status Pemanfaatan Dan Upaya Pelestarian Ikan Endemik Air Tawar Di Pulau Sumatera." Jurnal Kebijakan Perikanan Indonesia 8(2):101. doi: 10.15578/jkpi.8.2.2016.101-110.

Rahmawati, Hijjah, dan Hartono Dede. 2012. "Strategi Pengembangan Usaha Budidaya Ikan Air Tawar." NATURALIS 1(2):129-34.

Sarnita, A. S. 1993. "Pengelolaan Perikanan Danau Tempe." Buletin Penelitian Pusat Penelitian dan Pengembangan Perikanan 2:6-12.

Soewarno. 1991. Hidrologi Pengukuran dan Pengolahan Data Aliran Sungai (Hidrometri). Bandung (ID): Penerbit Nova.
Subagyo, H. 2006. Klasifikasi dan Penyebaran Rawa dalam Karakteristik Pengelolaan Lahan Rawa. Jakarta (ID): Balai Besar Penelitian dan Pengembangan Sumberdaya Lahan Pertanian, Departemen Pertanian.

Sunarno, Mas Tri Djoko, E. S. Kartamihardja, D. Nugroho, C. Umar, K. Amri, D. Oktaviani, A. Wibowo, dan Z. Fahmi. 2008. Kajian Potensi Sumber Daya Perikanan Darat dan Laut di Kalimantan Selatan. Banjarbaru (ID): Badan Penelitian dan Pengembangan Daerah Kalimantan Selatan.

Utomo, A. D., dan Asyari. 1999. "Peran ekosistem hutan rawa air tawar bagi kelestarian sumberdaya perikanan di sungai Kapuas, Kalimantan Barat." Journal Penelitian Perikanan Indonesia 5(3):1-13. 